\title{
Relationship between Flesh Firmness and Ground Color in Peach as Influenced by Light and Canopy Position
}

\author{
Kara Senger Lewallen and Richard P. Marini \\ Department of Horticulture, Virginia Polytechnic Institute and State University, Blacksburg, VA 24061-0327
}

\begin{abstract}
AdDitional INDEX words. Prunus persica, hue angle, fruit quality, photosynthetic photon flux
Abstract. The influence of photosynthetic photon flux $(P P F)$ on peach [Prunus persica $(\mathrm{L}$.) Batsch] fruit quality and the relationship between ground color and flesh firmness was studied by performing three experiments. Fruit with varying ground colors were sampled from different canopy positions with varying $P P F$. Fruit skin color was measured with a tristimulus colorimeter and values for $\mathrm{L}$ * (lightness), chroma (brightness), and hue angle (numerical values for color) were calculated for each fruit. Fruit from the canopy exterior generally were larger, had more surface area colored red, had higher soluble solids concentrations, and were darker, duller, and redder than fruit harvested from interior positions. In all three experiments, the relationship between hue angle and fruit firmness was affected by $P P F$, but the nature of the relationship (linear vs. curvilinear) and the influence of position was not consistent. When fruit were covered with aluminum foil or a section of the fruit surface was covered with duct tape to prevent light-induced red coloration of the skin, the relationship between hue angle and fruit firmness was similar for different canopy positions. Therefore, the relationship between ground color and fruit firmness is influenced by the light environment in which a fruit develops, and not by canopy position. Ground color does not seem to be a good indicator of fruit firmness because fruit with the same hue angle had greatly differing firmnesses.
\end{abstract}

As peaches [Prunus persica (L.) Batsch] ripen the color of the flesh and skin changes from green to yellow, because chlorophyll concentrations decline and carotenoids increase (Addoms et al., 1930; Seymour et al., 1993), and the flesh softens because waterinsoluble pectin is solubilized (Pressy and Avants, 1973), and decreases in cell wall protopectin and cellulose leads to a loss of cell wall integrity (Fishman et al., 1993). The side of the fruit exposed to light also develops red over-color (Erez and Flore, 1986) because anthocyanin is produced in the epidermal cells (Salunkhe and Kadam, 1995; Seymour et al., 1993). Changes in ground color and flesh firmness are generally related (Long and Webb, 1973; Sims and Comin, 1963) and are used as indicators of harvest maturity (Delwiche and Baumgarder, 1983, 1985; Upshall, 1946). After reviewing the literature on the use of ground color as a maturity index for peaches, Haller (1952) concluded that although ground color remains the principal guide to harvest, ground color is influenced by too many factors other than maturity to be used directly as an index of maturity. Because growth status of the tree appeared to influence ground color development, he suggested that ground color might be used as a maturity index after adjusting for tree growth status. During the last 50 years, little research has been directed at identifying the factors that affect ground color or factors that might influence the relationship between ground color and fruit firmness.

Factors such as light exposure (Erez and Flore, 1986: Marini, 1985; Rom et al., 1984), temperature (Bible and Singha, 1993), crop load (Dann and Jerie, 1988), water stress (Basiouny and Buchanan, 1977), and nitrogen fertilization (Daane et al., 1995) influence peach fruit color. It is unknown if these factors can influence the relationship between ground color and flesh firmness.

Canopy position influences peach fruit quality characteristics. Peaches in the top of the canopy were more purple, less orange-red, less firm, had higher sugar concentrations and $\mathrm{pH}$, and lower acid concentrations than fruit from the lower canopy (Genard and Bruchou, 1992; Marini, 1985; Marini and Trout, 1984; Rom et al., 1984). Although there are large gradients in photosynthetic photon flux $(P P F)$ related to canopy position in vase-shaped trees, the effect of canopy position may be somewhat independent of $P P F$. For example Genard and Bruchou (1992) reported that $P P F$ exposure

Received for publication 22 Jan. 2002. Accepted for publication 18 Nov. 2002. was not significantly correlated with canopy height. Dann and Jerie (1988) reported that maturation and fruit quality of peach fruit were influenced more by proximity to the roots than to light interception. Fruit developing farthest from the roots matured earliest, and had the greatest dry weight and soluble solids concentration. Results from a limb-shading experiment indicated that peach soluble solids concentration, surface red color, and flesh firmness, but not fruit weight, were reduced by shading (Marini etal., 1991). Fruit from shaded branches had greener ground color and softer flesh than fruit from nonshaded branches. This indicates that light or canopy position may alter the relationship between ground color and flesh firmness. If the relationship between ground color and flesh firmness is affected by canopy position or light exposure, then fruit from different canopy positions should be harvested with different ground colors.

The objectives of this study were to determine the influence of canopy position and $P P F$ on peach fruit quality characteristics, and to determine if canopy position and $P P F$ influence the relationship between ground color and fruit firmness.

\section{Materials and Methods}

EXPERIMENT 1-'NORMAN'. The purpose of this experiment was to evaluate the relationship between fruit firmness and ground color for fruit developing in varying light environments, at different canopy locations. Own-rooted 'Norman' trees, planted in 1988 with a north-south row orientation, were used in 1999. The trees were trained to the open vase form. There were three trees in each of six blocks. To ensure high $P P F$, only the south side of each tree was used for the experiment, and it was divided into three positions to provide a range of $P P F$. The "interior" position was located about $0.75 \mathrm{~m}$ from the trunk and about $0.75 \mathrm{~m}$ above ground and was heavily shaded. The "middle" position was located about $1.75 \mathrm{~m}$ from the trunk and $1.75 \mathrm{~m}$ above ground. The 'exterior' position was located $2.5 \mathrm{~m}$ from the trunk and $2.2 \mathrm{~m}$ above ground and the fruit were exposed to nearly full sun.

On 7 July 1999, six fruit per position per tree were randomly labeled 1 to 6 . One of three treatments was randomly assigned to one tree per block on 14 July ( $9 \mathrm{~d}$ before the first harvest date). In an attempt to separate the effects of canopy position and $P P F$, three treatments were selected to provide a range of $P P F$ at each canopy 
position. The following three treatments were selected to create a range of $P P F$ at each canopy position: 1) nontreated control, 2) to reduce $P P F, 73 \%$ neutral-density black polypropylene shade fabric (E.C. Geiger, Harleysville, Pa.), and 3) to increase PPF, aluminumcoated plastic mulch with a silver reflective appearance [1.5 mil (0.038 $\mathrm{mm}$ ) thickness, silveroverblack](Clarke Ag. Plastics, Greenwood, Va.). Shading consisted of covering the south side of the tree with shade fabric. PVC pipe, held in place with rebar steel, was arched in a X pattern over the canopy and was used to support the shade fabric with cinder blocks to anchor the corners of the cloth. Reflective mulch involved placing a 1.2-m-wide strip of reflective mulch on the ground, over a weed-free strip, under the south side of the tree. The film covered the ground from $0.65 \mathrm{~m}$ to $1.85 \mathrm{~m}$ from the trunk and was held in place with metal spikes and bamboo, so there was bare ground from 0.0 to $0.65 \mathrm{~m}$ and from 1.85 to $2.5 \mathrm{~m}$ from the trunk.

$P P F$ was measured in all 18 trees on 21 July and again on 22 July, with a light meter (LI-250; LI-COR, Lincoln, Nebr.) and a quantum sensor (LI-COR). Measurements were made between 1100 and 1300 HR. Because both days were partly overcast, $P P F$ data were variable, so data for the $2 \mathrm{~d}$ were averaged. In an attempt to measure the amount of light intercepted by a fruit, $P P F$ was measured on six sides of each fruit, following a reference measurement made above the tree. $P P F$ was measured by placing the sensor, facing away from the fruit, on the top, bottom, north, east, south, and west sides of each fruit. The six measurements were averaged for each fruit, and expressed as a percentage of the incident $P P F$ measured by placing the sensor facing skyward above the tree.

On 23 July 1999, one fruit per position per tree was harvested. Two normal size leaves per fruit were also removed from as close to the fruit as possible. Subsequent fruit and leaf samples were then harvested every other day, for a total of five harvest dates. A range of fruit maturity was obtained each day because fruit were harvested by label number rather than ground color. Therefore, the fruit harvested on a given date were representative of the population of fruit at that canopy position on that date. By the final harvest date (31 July) six of the 54 fruit had abscised, resulting in an unbalanced experiment.

Each fruit was weighed, and average flesh firmness was calculated from measurements made with an Effigi fruit tester fitted with a 7.9-mm tip (model FT 327; McCormick Fruit Tech., Yakima, Wash.) on the nonblush and the blush side of each fruit. The juice expressed while measuring flesh firmness was used to measure soluble solids concentration (SSC) with an Atago hand-held refractometer (model N 1; McCormick Fruit Tech.), calibrated for temperature. Skin ground color was measured in the CIELAB scale with a portable tristimulus colorimeter (CR-200; Minolta, Ramsy, N.J.) on the area of the fruit with the least red color. The internationally recognized color-space coordinates are designated as $\mathrm{L}^{*}, \mathrm{a}^{*}$, and $\mathrm{b}^{*}$. The lightness coefficient, $\mathrm{L}^{*}$, ranges from black $=0$ to white $=100$. Values of a* may be positive (red) or negative (green), and values of $b^{*}$ may be positive (yellow) or negative (blue). The meter was calibrated with a white standard $\left(L=97.83, a^{*}=-0.38, b^{*}=1.94\right)$. A copyrighted representation of three-dimensional color space can be observed at http://scholar.lib.vt.edu/theses/available/etd04262000-13090002/unrestricted/part3.pdf.

Values of $\mathrm{a}^{*}$ and $\mathrm{b}^{*}$ should not be used alone because they are not independent variables (Francis, 1980) and because they are difficult to interpret. A more appropriate measure of color can be obtained from the calculation of chroma and hue angle because they relate better than $a^{*}$ and $b^{*}$ to human perceptions (Thai and Shewfelt, 1990). Chroma is the degree of departure from gray or white towards the pure huecolor and is ameasure of brightness. Chromawascalculated as $\left(a^{* 2}+b^{* 2}\right)^{1 / 2}$. Hue angle quantifies color, where $0^{\circ}=$ red/purple, $90^{\circ}=$ yellow, and $180^{\circ}=$ bluish/green. Hue angle was calculated as [tan ${ }^{1}$ (b/a)] (McGuire, 1992). The area of each leaf was measured with a portable leaf area meter (LI-3000; LI-COR), and dry weight was recorded after drying at $93{ }^{\circ} \mathrm{C}$ for $4 \mathrm{~d}$. Specific leaf weight (SLW) was calculated by dividing the dry weight by the leaf area.

The experiment was a $3 \times 3 \times 5$ factorial in a split-plot design, with three canopy positions, three treatments, and five harvest dates. For each response variable, an analysis of variance (ANOVA) was performed with SAS's GLM Procedure (Littell et al., 1991). The model included block, harvest date, treatment, position, harvest date $\times$ treatment, harvest date $\times$ position, treatment $\times$ position, and harvest date $\times$ treatment $\times$ position. Least squares means were compared with the probability of the difference at the $5 \%$ level (PDIFF), which is the least significant difference (LSD) modified for unequal sample size. Analysis of covariance was performed where hue angle, measured on the greenest area of the fruit, was included as a covariate and the interaction for hue angle $\times$ treatment or hue angle $\times$ position was also included in the model. In cases where the covariate was significant $(P<0.05)$, least squares means, adjusted for the covariate, are reported. When the hue angle $\times$ position interaction was significant, polynomial regression was performed for each position to determine if flesh firmness was linearly or quadratically related to hue angle.

Experiment 2-'Cresthaven' 1999. This experiment was performed to determine the effect of exposing fruit to light on the relationship between fruit firmness and ground color for fruit harvested from different canopy positions. 'Cresthaven'/Halford peach trees, planted in 1988 with a north-south row orientation, were used in 1999. Tree spacing and size were similar to those of the 'Norman' trees. There were 12 trees in the experiment and each tree was considered to be a block. To obtain fruit from environments with maximum differences in light exposure, each tree was divided into two positions, "interior" and "exterior". The interior position was located $0.75 \mathrm{~m}$ from the trunk and $0.75 \mathrm{~m}$ above the ground on the north side of the tree. The exterior position was located $2.5 \mathrm{~m}$ from the trunk and $2.2 \mathrm{~m}$ above ground on the south side of the tree. The two sides of the tree were used to provide the maximum difference in light exposure. On 4 Aug. (16 d before the first harvest), six pairs of fruit per position per tree were tagged and treatments were applied. Treatments were 1) nontreated control, and 2) covered with aluminum foil. The foil was wrapped around the fruit and the seams were pinched together to prevent any light intrusion, without disturbing growth. One fruit per pair was covered and the other remained noncovered. Each pair of fruit was randomly numbered from 1 to 6 , which referred to the harvest date. Fruit were not picked on the basis of ground color, but instead were picked by harvest date number; thus, a range of fruit maturity was obtained on each harvest date.

Between 1100 and 1300 HR, on 9 and 11 Aug., PPF was measured on six sides of each noncovered fruit as previously described and data for the two measurements dates were averaged because the sky conditions were partly cloudy. The corresponding covered fruit was assumed to have similar light exposure. References above the tree were recorded before each set of measurements.

On 20 Aug., one pair of fruit per position per tree was harvested. The two normal-sized leaves closest to each noncovered fruit were also removed. Fruit and leaves were harvested every other day for a total of four harvest dates. Fruit weight and quality variables were measured as reported for 'Norman'. Statistical analyses were similar to those described for the 'Norman' experiment. Because this experiment was balanced, means were compared with Tukey's test.

EXPERIMENT 3-'CRESTHAVEN' 2000. The purpose of this experiment was to determine if fruit developing with varying exposure to 
Table 1. Photosynthetic photon flux $(P P F)$ and specific leaf weight (SLW) measured next to each 'Norman' peach as influenced by treatment and canopy position in 1999 .

\begin{tabular}{lrrrr}
\hline \hline & \multicolumn{3}{c}{$P P F(\%)^{\mathrm{z}}$} & $\begin{array}{c}\text { SLW } \\
\text { Variable }\end{array}$ \\
\cline { 2 - 4 } & Average & Top & Bottom & $\left(\mathrm{mg} \cdot \mathrm{cm}^{-2}\right)$ \\
\hline Treatment & $12.1 \mathrm{a}^{\mathrm{y}}$ & $29.0 \mathrm{a}$ & $2.6 \mathrm{~b}$ & $6.9 \mathrm{a}$ \\
$\quad$ Control & $14.2 \mathrm{a}$ & $32.7 \mathrm{a}$ & $8.2 \mathrm{a}$ & $6.7 \mathrm{a}$ \\
$\quad$ Reflective mulch & $8.2 \mathrm{~b}$ & $25.4 \mathrm{a}$ & $2.5 \mathrm{~b}$ & $6.2 \mathrm{~b}$ \\
$\quad$ Shade & & & & \\
Position & $6.5 \mathrm{~b}$ & $15.2 \mathrm{~b}$ & $3.4 \mathrm{~b}$ & $6.0 \mathrm{~b}$ \\
$\quad$ Interior & $7.9 \mathrm{~b}$ & $18.2 \mathrm{~b}$ & $5.5 \mathrm{a}$ & $6.2 \mathrm{~b}$ \\
$\quad$ Middle & $20.1 \mathrm{a}$ & $53.7 \mathrm{a}$ & $4.4 \mathrm{~b}$ & $7.4 \mathrm{a}$ \\
$\quad$ Exterior & 0.004 & 0.547 & 0.001 & 0.001 \\
ANOVA $P$ values & 0.001 & 0.001 & 0.056 & 0.001 \\
$\quad$ Treatment (T) & 0.080 & 0.080 & 0.441 & 0.937 \\
$\quad$ Position (P) & & & & \\
$\quad$ T $\times$ P & & &
\end{tabular}

$\overline{\mathrm{z} V \text { alues are the least squares means of six measurements per fruit. The }}$ quantum sensor was placed next to the fruit facing east, west, north, south, up, and down.

${ }^{\mathrm{y}}$ Values are the least squares means of 90 observations per treatment, and 90 observations per position. Separation of least squares means within columns and variables by the probability of the difference, $5 \%$ level.

$P P F$ related to canopy location, and harvested with similar ground color, without interference of anthocyanin, had similar firmness. Six 'Cresthaven' trees planted in 1988, but not used in 1999, were selected for uniformity in July 2000. On 1 Aug., 20 fruit were randomly selected on the exterior south side and interior north side of each tree and a piece of duct tape $(\approx 2 \times 2 \mathrm{~cm})$ was placed on the shaded side of each fruit. In an attempt to harvest fruit with similar maturities, all exterior fruit were harvested on 14 Aug. and all interior fruit were harvested on 16 Aug. At harvest, each fruit was weighed and the percentage of the fruit surface colored red was visually rated and recorded. $\mathrm{L}^{*}, \mathrm{a}^{*}$, and $\mathrm{b}^{*}$ were measured on the nonred side of each fruit about $1.5 \mathrm{~cm}$ to the side of the tape. The tape was then removed and measurements were repeated on the yellow skin that had been covered with tape. Fruit skin was not removed by tape removal. Flesh firmness was then measured on two sides of each fruit.

The factorial experiment ( 2 treatments $\times 2$ canopy positions), with subsampling, was analyzed as a RCBD by ANOVA with SAS's Mixed procedure (Littell et al., 1996). Tree was considered the block, and trees and subsamples were designated as random effects. The variables in the model were treatment (tape vs. no tape), position, and treatment $\times$ position, and the response variables were fruit weight, percentage of fruit surface with red color, flesh firmness, hue angle, $\mathrm{L}^{*}$, and chroma. Analyses of covariance were performed; where flesh firmness was the response variable and hue angle under the tape or beside the tape was the covariate. The interaction terms hue angle $\times$ position, hue angle $\times$ treatment and hue angle $\times$ position $\times$ treatment were added to the model. The hue angle $\times$ position interaction was significant $(P=0.01)$, so polynomial regression models were fit for each position, where flesh firmness was the response variable and hue angle was the regressor variable.

\section{Results}

'Norman'. PPF values measured on top of the fruit (sensor facing skyward), the bottom of the fruit (sensor facing toward the

Table 2. Fruit size, flesh firmness, soluble solids concentration (SSC), and surface color measurements of 'Norman' peach as Influenced by harvest date, light treatments, and canopy position in 1999 . $^{\mathrm{z}}$

\begin{tabular}{|c|c|c|c|c|c|c|c|c|c|}
\hline \multirow[b]{2}{*}{ Variable } & \multirow{2}{*}{$\begin{array}{l}\text { Fruit } \\
\text { wt } \\
(\mathrm{g})\end{array}$} & \multirow{2}{*}{$\begin{array}{c}\text { Flesh } \\
\text { firmness } \\
(\mathrm{N})\end{array}$} & \multirow[b]{2}{*}{$\begin{array}{c}\mathrm{SSC} \\
(\%)\end{array}$} & \multicolumn{3}{|c|}{ Blush side ${ }^{y}$} & \multicolumn{3}{|c|}{ Nonblush side ${ }^{y}$} \\
\hline & & & & $\mathrm{L}^{*}$ & $\begin{array}{c}\text { Hue } \\
\text { angle }\end{array}$ & Chroma & $\mathrm{L}^{*}$ & $\begin{array}{c}\text { Hue } \\
\text { angle }\end{array}$ & Chroma \\
\hline \multicolumn{10}{|l|}{$\overline{\text { Date }}$} \\
\hline 23 July & $103.4 \mathrm{~d}^{\mathrm{x}}$ & $44.0 \mathrm{a}$ & $10.8 \mathrm{a}$ & $43.8 \mathrm{a}$ & $45.4 \mathrm{a}$ & 35.2 & $67.8 \mathrm{a}$ & 89.7 a & $46.6 \mathrm{~cd}$ \\
\hline 25 July & $108.9 \mathrm{~cd}$ & $42.8 \mathrm{a}$ & $10.6 \mathrm{a}$ & $43.9 \mathrm{a}$ & $42.5 \mathrm{a}$ & 35.2 & $67.8 \mathrm{a}$ & 86.9 a & $45.9 \mathrm{~d}$ \\
\hline 27 July & $113.7 \mathrm{bc}$ & $31.0 \mathrm{~b}$ & $10.6 \mathrm{a}$ & $41.1 \mathrm{~b}$ & $37.0 \mathrm{~b}$ & 36.1 & $66.1 \mathrm{ab}$ & $79.3 \mathrm{~b}$ & $47.9 \mathrm{ab}$ \\
\hline 29 July & $120.5 \mathrm{ab}$ & $27.0 \mathrm{~b}$ & $10.9 \mathrm{a}$ & $40.2 \mathrm{bc}$ & $35.5 \mathrm{~b}$ & 35.8 & $64.9 \mathrm{bc}$ & $75.8 \mathrm{~b}$ & $47.3 \mathrm{bc}$ \\
\hline 31 July & $127.8 \mathrm{a}$ & $15.8 \mathrm{c}$ & $6.4 \mathrm{~b}$ & $37.9 \mathrm{c}$ & $30.2 \mathrm{c}$ & 34.7 & $62.8 \mathrm{c}$ & $68.0 \mathrm{c}$ & 48.8 a \\
\hline \multicolumn{10}{|l|}{ Treatment } \\
\hline Control & $113.7 \mathrm{~b}$ & 33.6 & $10.7 \mathrm{a}$ & $39.0 \mathrm{~b}$ & $33.6 \mathrm{~b}$ & $34.1 \mathrm{~b}$ & $65.4 \mathrm{~b}$ & $78.9 \mathrm{~b}$ & $46.7 \mathrm{~b}$ \\
\hline Reflective mulch & $120.6 \mathrm{a}$ & 29.5 & $10.8 \mathrm{a}$ & $37.1 \mathrm{c}$ & $29.9 \mathrm{c}$ & $32.6 \mathrm{~b}$ & $63.2 \mathrm{c}$ & $73.3 \mathrm{c}$ & $46.8 \mathrm{~b}$ \\
\hline Shade & $110.4 \mathrm{~b}$ & 33.1 & $8.0 \mathrm{~b}$ & $48.0 \mathrm{a}$ & $51.0 \mathrm{a}$ & $39.6 \mathrm{a}$ & $69.1 \mathrm{a}$ & $87.6 \mathrm{a}$ & $48.4 \mathrm{a}$ \\
\hline \multicolumn{10}{|l|}{ Position } \\
\hline Interior & $104.3 \mathrm{c}$ & $39.9 \mathrm{a}$ & $9.3 \mathrm{c}$ & $44.5 \mathrm{a}$ & $44.9 \mathrm{a}$ & $36.1 \mathrm{a}$ & $67.8 \mathrm{a}$ & $86.9 \mathrm{a}$ & $46.6 \mathrm{~b}$ \\
\hline Middle & $112.5 \mathrm{~b}$ & $36.7 \mathrm{a}$ & $9.8 \mathrm{~b}$ & $44.2 \mathrm{a}$ & $42.7 \mathrm{a}$ & $36.2 \mathrm{a}$ & $66.8 \mathrm{a}$ & $82.4 \mathrm{~b}$ & $46.8 \mathrm{~b}$ \\
\hline Exterior & $127.9 \mathrm{a}$ & $19.8 \mathrm{~b}$ & $10.4 \mathrm{a}$ & $35.4 \mathrm{~b}$ & $26.8 \mathrm{~b}$ & $33.8 \mathrm{~b}$ & $63.2 \mathrm{~b}$ & $70.6 \mathrm{c}$ & $48.5 \mathrm{a}$ \\
\hline \multicolumn{10}{|l|}{ ANOVA $P$ values } \\
\hline Date (D) & 0.001 & 0.001 & 0.001 & 0.001 & 0.001 & 0.737 & 0.001 & 0.001 & 0.002 \\
\hline Treatment (T) & 0.008 & 0.258 & 0.001 & 0.001 & 0.001 & 0.001 & 0.001 & 0.001 & 0.001 \\
\hline Position (P) & 0.001 & 0.001 & 0.001 & 0.001 & 0.001 & 0.003 & 0.001 & 0.001 & 0.001 \\
\hline $\mathrm{D} \times \mathrm{T}$ & 0.028 & 0.808 & 0.022 & 0.854 & 0.921 & 0.028 & 0.520 & 0.306 & 0.312 \\
\hline $\mathrm{D} \times \mathrm{P}$ & 0.100 & 0.752 & 0.528 & 0.633 & 0.274 & 0.918 & 0.663 & 0.756 & 0.994 \\
\hline $\mathrm{T} \times \mathrm{P}$ & 0.100 & 0.118 & 0.624 & 0.001 & 0.001 & 0.472 & 0.117 & 0.706 & 0.395 \\
\hline $\mathrm{D} \times \mathrm{T} \times \mathrm{P}$ & 0.900 & 0.985 & 0.597 & 0.784 & 0.620 & 0.613 & 0.898 & 0.795 & 0.925 \\
\hline
\end{tabular}

${ }^{\mathrm{z}}$ Values are the least squares means of 54 fruit per harvest date, 90 fruit per treatment, and 90 fruit per position.

$\mathrm{y}_{\mathrm{L}}^{*}=$ lightness; chroma $=\left[\left(\mathrm{a}^{* 2}+\mathrm{b}^{* 2}\right)^{1 / 2}\right]$; hue angle $=$ arctangent $\mathrm{b}^{*} / \mathrm{a}^{*}$, where $0^{\circ}=$ red-purple, $90^{\circ}=$ yellow, $180^{\circ}=$ bluish-green, and $270^{\circ}=$ blue.

${ }^{x}$ Least squares means separation within columns and variables by the probability of the difference, $5 \%$ level. 
ground), and the average of the four cardinal directions plus the top and bottom of each fruit are presented in Table 1. Average PPF was similar for the control and reflective mulch treatments, but lower under the shade cloth. Average PPF was highest for exterior fruit and was similar for fruit from interior and middle canopy positions. As with average $P P F, P P F$ measured above the fruit was highest for exterior fruit. $P P F$ measured at the bottom of each fruit was highest for fruit on reflective mulch-treated trees, and for fruit at the middle canopy position. SLW was lowest for leaves on shaded trees and highest for exterior leaves on nonshaded trees. Within a position, SLW fluctuated from day to day, probably due to small sample size (data not presented).

In general, fruit weight increased as harvest date was delayed (Table 2). Fruit weight was highest on trees with reflective mulch, and for fruit from the canopy exterior, followed by middle, and interior positions. Flesh firmness decreased from the first to the last harvest date. Fruit from the interior and middle positions were similar in firmness, and both were firmer than the exterior fruit. Average flesh firmness was not affected by treatment.

SSC was similar for the first four harvest dates, and then declined approximately four percent on the last date. The decline was probably due to dilution caused by $3.3 \mathrm{~cm}$ of precipitation the night before the last harvest. The interaction of harvest date $\times$ treatment was significant but shaded fruit always had the lowest SSC (data not shown). For all dates, all positions differed significantly from each other, and exterior fruit had the highest SSC whereas interior fruit had the lowest SSC.

As harvest date progressed, values of $\mathrm{L}^{*}$ and hue angle declined as fruit became darker and changed from orange to orange-red (Table 2). For all treatments, values for $\mathrm{L}^{*}$ and hue angle were lowest (darker and redder) for fruit harvested from the canopy exterior. For fruit from trees with reflective mulch, $L^{*}$ values were lowest (darkest) for exterior fruit, highest (lightest) for interior fruit and intermediate for middle fruit (data not shown). For the other treatments, $\mathrm{L}^{*}$ values were similar for fruit from the interior and middle positions, and exterior fruit had the lowest $\mathrm{L}^{*}$ values. The blush side of fruit from shaded trees had the highest hue angles (more yellow and less red), regardless of canopy position (Fig. 1). Compared to control trees, reflective mulch resulted in lower hue angles (more red) on the blush side of fruit from interior and middle, but not the exterior, positions. Chroma (brightness) on the blush side was significantly affected by treatment, position, and the interaction of harvest date $\times$ treatment (Table 2). Within treatments, chroma fluctuated randomly with harvest date (data not shown). Chroma values were highest (brightest) for fruit from shaded trees, and lowest (darkest) for exterior fruit.

Values for L*, hue angle, and chroma on the nonblush side of the fruit were significantly affected by harvest date, treatment, and position (Table 2). From the first harvest date to the last, the fruit became darker and duller, and changed from yellow to yelloworange. All three treatments differed from each other. Fruit from shaded trees were the lightest, greenest, and brightest, whereas fruit from trees with reflective mulch were the darkest and reddest. Fruit from the reflective mulch-treated trees and control trees had similar chroma values, and were duller than shaded fruit. Values for $\mathrm{L}^{*}$ and chroma were lowest for exterior fruit. Regardless of treatment, hue angle on the nonblush side was highest (less red) for interior fruit and lowest for exterior fruit (more red) (data not shown). For all canopy positions, the nonblush side of fruit from shaded trees had the highest hue angle values (less red).

The relationship between hue angle on the nonblush side of the fruit and flesh firmness was not influenced by treatment, but the relationships varied for the three canopy positions. The relationship between hue angle on the nonblush side and firmness was curvilinear for all three positions (Fig. 1). This relationship became more variable as fruit sampling progressed from the interior to the exterior of the tree; coefficients of determination were $0.65,0.60$, and 0.50 respectively for interior, middle, and exterior fruit (Fig. 1). When harvested with orange ground color (hue angle $=60^{\circ}$ ), exterior fruit were about $7 \mathrm{~N}$ softer than fruit from the other positions. When harvested with yellowish-green ground color $\left(100^{\circ}\right)$, fruit from all positions had similar firmness.

'Cresthaven' 1999. Average PPF measured around the fruit and SLW of leaves developing next to the fruit were influenced by canopy position. $P P F$ was $5.1 \%$ of full sun at the tree interior and $21.0 \%$ at the exterior. SLW was 6.8 and $8.2 \mathrm{mg} \cdot \mathrm{cm}^{-2}$, respectively
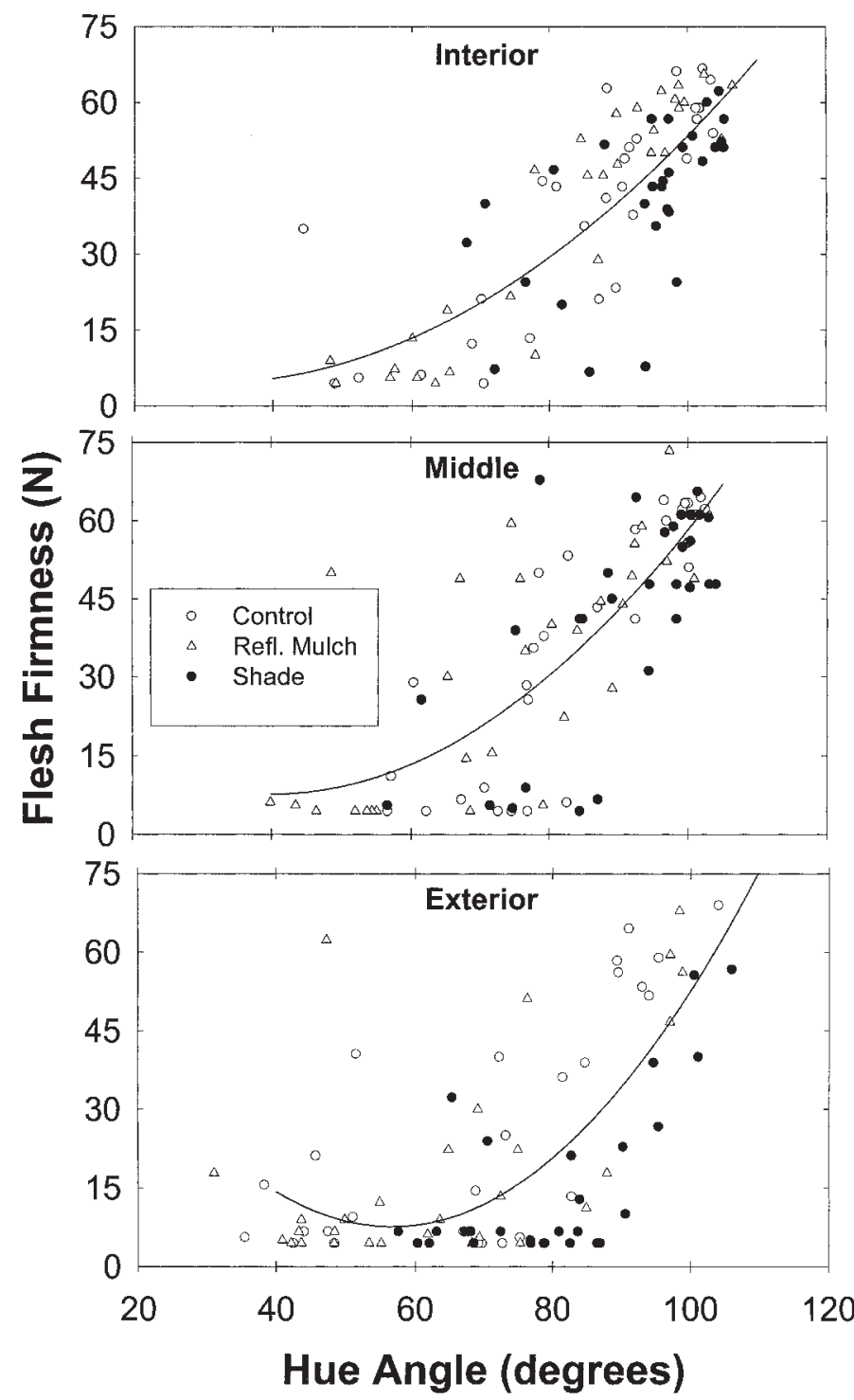

Fig. 1. The relationship between flesh firmness and hue angle measured on the nonblush side of 'Norman' fruit in 1999 (Expt. 1). Fruit were harvested from control trees $(\bigcirc)$, trees with reflective mulch on the ground $(\Delta)$, and trees covered with $73 \%$ shade fabric ( ). Regression models: For interior fruit, flesh firmness $(\mathrm{N})=13.42-0.60$ (hue angle) +0.01 (hue angle $\left.{ }^{2}\right), r^{2}=0.65$; for middle fruit, flesh firmness $=30.22-1.08$ (hue angle) $+0.01\left(\right.$ hue angle $\left.{ }^{2}\right), r^{2}=0.60$; for exterior fruit, flesh firmness $=84.62-2.72$ (hue angle) $+0.024\left(\right.$ hue angle $\left.{ }^{2}\right), r^{2}$ $=0.50 . \mathrm{L}^{*}=$ lightness; chroma $=\left[\left(\mathrm{a}^{* 2}+\mathrm{b}^{* 2}\right)^{1 / 2}\right]$; hue angle $=\operatorname{arctangent} \mathrm{b}^{*} / \mathrm{a}^{*}$, where $0^{\circ}=$ red-purple, $90^{\circ}=$ yellow, $180^{\circ}=$ bluish-green, and $270^{\circ}=$ blue . 
Table 3. Fruit size, flesh firmness, soluble solids concentration (SSC), and surface color measurements of 'Cresthaven' peach as influenced by harvest date, covering fruit with foil, and canopy position in $1999 .{ }^{\mathrm{z}}$

\begin{tabular}{|c|c|c|c|c|c|c|c|c|c|}
\hline \multirow[b]{2}{*}{ Variable } & \multirow{2}{*}{$\begin{array}{l}\text { Fruit } \\
\text { wt } \\
(\mathrm{g})\end{array}$} & \multirow{2}{*}{$\begin{array}{c}\text { Flesh } \\
\text { firmness } \\
(\mathrm{N})\end{array}$} & \multirow[b]{2}{*}{$\begin{array}{l}\mathrm{SSC} \\
(\%)\end{array}$} & \multicolumn{3}{|c|}{ Blush side ${ }^{y}$} & \multicolumn{3}{|c|}{ Nonblush side ${ }^{y}$} \\
\hline & & & & $\mathrm{L}^{*}$ & $\begin{array}{c}\text { Hue } \\
\text { angle }\end{array}$ & Chroma & $\mathrm{L}^{*}$ & $\begin{array}{c}\text { Hue } \\
\text { angle }\end{array}$ & Chroma \\
\hline \multicolumn{10}{|l|}{ Date } \\
\hline 20 Aug. & $140.2 b^{x}$ & $32.4 \mathrm{a}$ & 7.5 & 55.6 & 55.2 & 47.9 & 74.5 & $85.9 \mathrm{a}$ & $52.4 \mathrm{ab}$ \\
\hline 22 Aug. & $143.8 \mathrm{~b}$ & $20.8 \mathrm{~b}$ & 7.7 & 56.8 & 55.9 & 46.8 & 72.9 & $80.6 \mathrm{~b}$ & $51.6 \mathrm{~b}$ \\
\hline 24 Aug. & $162.9 \mathrm{a}$ & $16.0 \mathrm{bc}$ & 7.5 & 56.9 & 55.2 & 47.1 & 73.5 & $78.4 \mathrm{~b}$ & $53.7 \mathrm{a}$ \\
\hline 26 Aug. & $160.2 \mathrm{a}$ & $14.6 \mathrm{c}$ & 7.2 & 56.8 & 55.0 & 47.9 & 73.6 & $78.8 \mathrm{~b}$ & $53.5 \mathrm{a}$ \\
\hline \multicolumn{10}{|l|}{ Treatment } \\
\hline Covered & 158.1 & 18.7 & 7.0 & 74.5 & 82.0 & 58.1 & 78.2 & 87.9 & 56.2 \\
\hline Noncovered & 145.5 & 23.2 & 8.1 & 38.6 & 28.7 & 36.4 & 69.0 & 73.9 & 49.5 \\
\hline \multicolumn{10}{|l|}{ Position } \\
\hline Interior & 145.7 & 22.7 & 6.8 & 58.9 & 59.6 & 48.5 & 74.4 & 83.0 & 52.3 \\
\hline Exterior & 157.9 & 19.3 & 8.2 & 54.2 & 51.1 & 46.0 & 72.8 & 78.8 & 53.4 \\
\hline \multicolumn{10}{|l|}{ ANOVA $P$ values } \\
\hline Date (D) & 0.001 & 0.001 & 0.149 & 0.649 & 0.961 & 0.772 & 0.386 & 0.001 & 0.004 \\
\hline Treatment $(\mathrm{T})$ & 0.002 & 0.001 & 0.001 & 0.001 & 0.001 & 0.001 & 0.001 & 0.001 & 0.001 \\
\hline Position (P) & 0.003 & 0.044 & 0.001 & 0.001 & 0.001 & 0.001 & 0.020 & 0.001 & 0.025 \\
\hline $\mathrm{D} \times \mathrm{T}$ & 0.999 & 0.487 & 0.357 & 0.942 & 0.887 & 0.579 & 0.075 & 0.034 & 0.314 \\
\hline $\mathrm{D} \times \mathrm{P}$ & 0.067 & 0.968 & 0.140 & 0.028 & 0.462 & 0.030 & 0.501 & 0.986 & 0.593 \\
\hline $\mathrm{T} \times \mathrm{P}$ & 0.698 & 0.152 & 0.169 & 0.001 & 0.001 & 0.001 & 0.061 & 0.206 & 0.226 \\
\hline $\mathrm{D} \times \mathrm{T} \times \mathrm{P}$ & 0.946 & 0.777 & 0.604 & 0.332 & 0.875 & 0.499 & 0.910 & 0.978 & 0.608 \\
\hline
\end{tabular}

${ }^{\mathrm{z}}$ Values are the means of 48 fruit per harvest date, 96 fruit per treatment, and 96 fruit per position.

$\mathrm{y}_{\mathrm{L}}^{*}=$ lightness; chroma $=\left[\left(\mathrm{a}^{* 2}+\mathrm{b}^{* 2}\right)^{1 / 2}\right]$; hue angle $=$ arctangent $\mathrm{b}^{*} / \mathrm{a}^{*}$, where $0^{\circ}=$ red-purple, $90^{\circ}=$ yellow, $180^{\circ}=$ bluish-green, $270^{\circ}=$ blue.

${ }^{x}$ Mean separation within columns and variables by the probability of the difference, $5 \%$ level.

for interior and exterior leaves; these values were significantly different $(P=0.001)$. Fruit weight increased as the harvest season progressed (Table 3). Fruit weight was greater for foil-covered fruit than for noncovered fruit, and fruit weight was greater for exterior fruit than for interior fruit. Flesh firmness was greatest on the first sampling date and lowest on the last two dates. Noncovered fruit were firmer than foil-covered fruit, and interior fruit were firmer than exterior fruit. Harvest date did notinfluence SSC, but noncovered fruit had higher SSC than covered fruit, and exterior fruit had higher SSC than interior fruit. Flesh firmness was not significantly related to SSC.

Values for $\mathrm{L}^{*}$ and chroma on the blush side of the fruit were significantly affected by treatment, position, harvest date $\times$ position, and treatment $\times$ position. $L^{*}$ and chroma values were similar for fruit from both positions on the first harvest. During the harvest period, values for $\mathrm{L}^{*}$ and chroma increased (fruit became lighter and brighter) for the interior fruit and declined for exterior fruit (data not shown). Hue angle on the blush side was significantly affected by treatment, position, and the interaction of treatment $\times$ position. Hue angle was not affected by harvest date. Covered fruit were orangeyellow, whereas noncovered fruit were purplish-red. Exterior fruit were redder than interior fruit. Hue angle on noncovered fruit, but not covered fruit, was affected by position. Hue angles were $82^{\circ}$ and $80^{\circ}$ for interior and exterior covered fruit, respectively, and $35^{\circ}$ and $22^{\circ}$ for interior and exterior noncovered fruit, respectively.

Noncovered fruit were darker (Lower $L^{*}$ ) than covered fruit, and exterior fruit were darker than interior fruit. Covered fruit remained yellow throughout the harvest period (Table 3). From the first to the last harvest date, the hue angle of covered fruit changed from $90^{\circ}$ to $87^{\circ}$. During the same period, ground color of noncovered fruit changed from orange-yellow $\left(82^{\circ}\right)$ to yellow-orange $\left(70^{\circ}\right)$. Over time, the fruit became slightly brighter (chroma increased). Covered fruit were brighter than noncovered fruit, and exterior fruit were brighter than interior fruit (Table 3).

The relationship between hue angle on the nonblushed side and flesh firmness differed among treatments and positions for 'Cresthaven' fruit (Fig. 2). The relationship was linear for interior covered fruit, and curvilinear for the other position/treatment combinations and the three curves were not homogenous.

The relationships between hue angle and firmness were similar for both positions when fruit were covered to eliminate light; at a given hue angle fruit from both positions had similar firmness. The lowest hue angle recorded for covered fruit was about $78^{\circ}$, which corresponds to an orange-yellow color; noncovered fruit had hue angles $<45^{\circ}$, corresponding to red.

'CResthaVEN' 2000. Exterior fruit had greater fruit weight and red surface color than interior fruit, but firmness was not influenced by position (Table 4). The noncovered skin of exterior fruit had higher values for $\mathrm{L}^{*}$ and chroma (lighter and brighter), but lower hue angles than the noncovered skin of interior fruit. Color variables, measured under the tape, were not influenced by canopy position. For skin under the tape, values of $\mathrm{L}^{*}$, chroma, and hue angle were all higher than for noncovered skin. Therefore, the yellow skin under the tape was lighter and brighter than the orange skin beside the tape. It is not known if pubescence removal by the tape had an effect on color measurements. Although fruit firmness from both canopy positions ranged from about $3 \mathrm{~N}$ to $55 \mathrm{~N}$, the hue angles of noncovered skin varied from $4^{\circ}$ to $57^{\circ}$ for exterior fruit and from $23^{\circ}$ to $88^{\circ}$ for interior fruit. Therefore, there was a poor relationship between hue angle of the noncovered skin and flesh firmness (Fig. 3). When color was measured next to the tape, fruit with hue angles from $25^{\circ}$ to $55^{\circ}$ were about $12 \mathrm{~N}$ firmer for exterior fruit. Hue angle of covered skin varied from about $70^{\circ}$ to $98^{\circ}$ (orange-yellow to greenish-yellow). The relationship between hue angle under the tape and flesh firmness was very poor and was not affected by canopy position; fruit with a hue angle of $90^{\circ}$ varied in firmness from $4 \mathrm{~N}$ to $98 \mathrm{~N}$. 


\section{Discussion}

This study consisted of three different, but related experiments. Preliminary experiments with 'Redhaven' and 'Biscoe' trees ( data

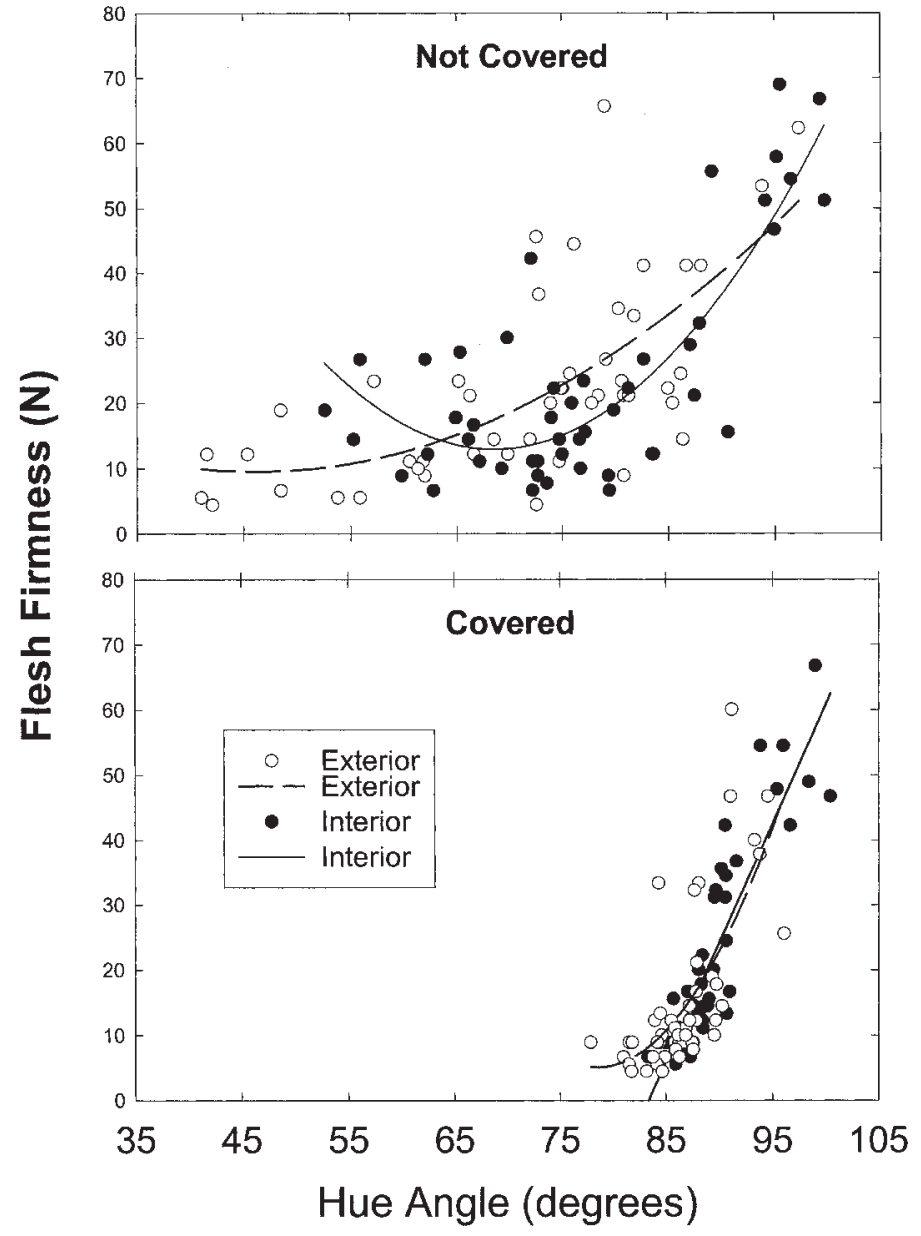

Fig. 2. The relationship between flesh firmness $(\mathrm{N})$ and hue angle measured on the nonblush side of 'Cresthaven' peaches in 1999 (Expt. 2). Fruit developing at tree interior $(\bigcirc)$ and exterior $(\bigcirc)$ were not covered or were covered with aluminum foil for $21 \mathrm{~d}$ before harvest. Regression models: For noncovered exterior fruit, flesh firmness $(\mathrm{N})=43.5-1.47$ (hue angle $)+0.016\left(\right.$ hue angle $\left.^{2}\right), r^{2}=0.45$; for noncovered interior fruit, flesh firmness $=254.7-7.04$ (hue angle) +0.051 (hue angle $\left.{ }^{2}\right), r^{2}=0.68$; for covered interior fruit, flesh firmness $(\mathrm{N})=83.02-$ 21.19(hue angle) $+0.14\left(\right.$ hue angle $\left.{ }^{2}\right), r^{2}=0.50$; for covered interior fruit, flesh firmness $=305.11-3.66$ (hue angle),$r^{2}=0.80 . \mathrm{L}^{*}=$ lightness; chroma $=\left[\left(\mathrm{a}^{* 2}\right.\right.$ $\left.+\mathrm{b}^{* 2}\right)^{1 / 2}$; hue angle $=$ arctangent $\mathrm{b}^{*} / \mathrm{a}^{*}$, where $0^{\circ}=$ red-purple, $90^{\circ}=$ yellow $180^{\circ}=$ bluish-green, and $270^{\circ}=$ blue. not shown) indicated that flesh firmness was linearly related to hue angle. At hue angles $>95^{\circ}$ firmness was similar for fruit from exterior and interior positions, but interior fruit were firmer than exterior fruit when hue angles were $<90^{\circ}$ (data not presented). We could not determine if flesh firmness was influenced by canopy position or light because the two factors were confounded. In an attempt to separate the effects of canopy position and $P P F$, the experiments described in this report were designed to provide a range of $P P F$ at each canopy position.

Treatments applied to 'Norman' trees effectively created a range of $P P F$ levels at each canopy position. Reflective mulch increased the amount of $P P F$ intercepted by fruit, especially on the underside of the fruit. Covering a side of the tree with shade cloth reduced the amount of $P P F$ intercepted by the fruit, and fruit on control trees were exposed to intermediate $P P F$ levels. However, $P P F$ levels were still related to canopy position. Exterior fruit received the most $P P F$, interior fruit received the least $P P F$, and fruit from the middle region of the canopy were exposed to intermediate $P P F$ levels. As expected, interior leaves, which were shaded for the entire season, had low SLW, but leaves from the exterior and middle positions had similar SLW. These midseason results agree with a previous report for peach (Marini and Marini, 1983). Reflective mulch did not increase $P P F$ enough to influence SLW, but SLW was reduced by shade. Treatments were applied only $9 \mathrm{~d}$ before harvest, which was probably not adequate time to cause modifications in leaf morphology associated with long-term exposure to low PPF levels (Wooge and Barden, 1987). The major components of SLW, which may be influenced by short-term modifications in light regime, are soluble sugars and/or starch. The low SLW of shaded leaves was probably related to reduced starch accumulation caused by low photosynthetic rates. Pickett (1935) used the diurnal changes in SLW as a measure of photosynthesis.

Reflective mulch increased $P P F$ levels enough to increase red color development on the blushed and nonblushed sides of the fruit. These data support the results of Layne et al. (2001), where reflective mulch improved peach red color. The influence of the treatments on fruit color development is obvious in Fig. 1. Few fruit from shaded trees had orange ground color (hue angle $=60^{\circ}$ ), and most shaded fruit had yellow to greenish/yellow (hue angle $90^{\circ}$ to $105^{\circ}$ ), whereas the ground color of fruit from control trees or trees with reflective mulch ranged from orange-red $\left(40^{\circ}\right)$ to greenishyellow $\left(105^{\circ}\right)$. As in the preliminary experiments, the relationship between fruit firmness and ground color, as measured by hue angle, was influenced by canopy position. Unlike for 'Biscoe' and 'Redhaven', the regression models were quadratic for 'Norman', probably because 'Norman' fruit were more mature and redder than

Table 4. Fruit quality characteristics of 'Cresthaven' fruit harvested from the exterior and interior canopy with and without a piece of duct tape on the shaded side to prevent development of red pigment in the fruit skin in $2000(\mathrm{n}=97) .^{\mathbf{z}}$

\begin{tabular}{|c|c|c|c|c|c|c|c|}
\hline $\begin{array}{l}\text { Canopy } \\
\text { position }\end{array}$ & Tape & $\begin{array}{c}\text { Fruit } \\
\text { wt } \\
(\mathrm{g})\end{array}$ & $\begin{array}{l}\text { Red } \\
\text { color } \\
(\%)\end{array}$ & $\begin{array}{c}\text { Firmness } \\
(\mathrm{N})\end{array}$ & $\mathrm{L}^{*}$ & Chroma & $\begin{array}{c}\text { Hue } \\
\text { angle } \\
\left(^{\circ}\right)\end{array}$ \\
\hline \multirow[t]{2}{*}{ Exterior } & No & 181 & 75 & 47.2 & 67.9 & 48.8 & 53.1 \\
\hline & Yes & --- & --- & --- & 75.1 & 54.2 & 86.3 \\
\hline \multirow{2}{*}{ Interior } & No & 165 & 41 & 50.5 & 56.2 & 44.4 & 72.4 \\
\hline & Yes & --- & --- & --- & 74.9 & 55.1 & 87.9 \\
\hline \multicolumn{8}{|l|}{$P$ value } \\
\hline Position (P) & & 0.028 & 0.002 & 0.414 & 0.008 & 0.014 & 0.001 \\
\hline Tape $(\mathrm{T})$ & & --- & --- & --- & 0.001 & 0.001 & 0.001 \\
\hline $\mathrm{P} \times \mathrm{T}$ & & --- & --- & --- & 0.204 & 0.086 & 0.008 \\
\hline
\end{tabular}

${ }^{\mathrm{Z}} \mathrm{L}^{*}=$ lightness; chroma $=\left[\left(\mathrm{a}^{* 2}+\mathrm{b}^{* 2}\right)^{1 / 2}\right]$; hue angle $=$ arctangent $\mathrm{b}^{*} / \mathrm{a}^{*}$, where $0^{\circ}=$ red-purple, $90^{\circ}=$ yellow, $180^{\circ}=$ bluish-green, $270^{\circ}=$ blue 
fruit in the preliminary experiments. Regression models were similar for fruit from the middle and interior positions, but the model for exterior fruit was different than the other positions. Fruit with orange and red-orange ground color (hue angle $<60^{\circ}$ ) were firmest when harvested from the middle and interior positions, but fruit harvested with greenish-yellow ground color (hue angle $=100^{\circ}$ ) had similar firmness at all positions. These results agree with those of the preliminary experiments. At a given hue angle, fruit from all positions on shaded trees tended to be less firm than fruit from trees with other treatments. The percentage of observations from shaded trees falling below the predicted curve in Fig. 1 was $89 \%, 55 \%$, and $72 \%$, for exterior, middle, and interior fruit respectively. Had shade not affected flesh firmness, then only about $50 \%$ of the observations would be expected to fall below the curve predicted by the regression model. These data agree with previous observations, where fruit from shaded limbs were greener and softer than fruit from nonshaded limbs (Marini et al., 1991). Although we are aware of no supporting evidence, assimilate availability may have been inadequate to maintain normal cell wall structure in fruit on shaded trees.

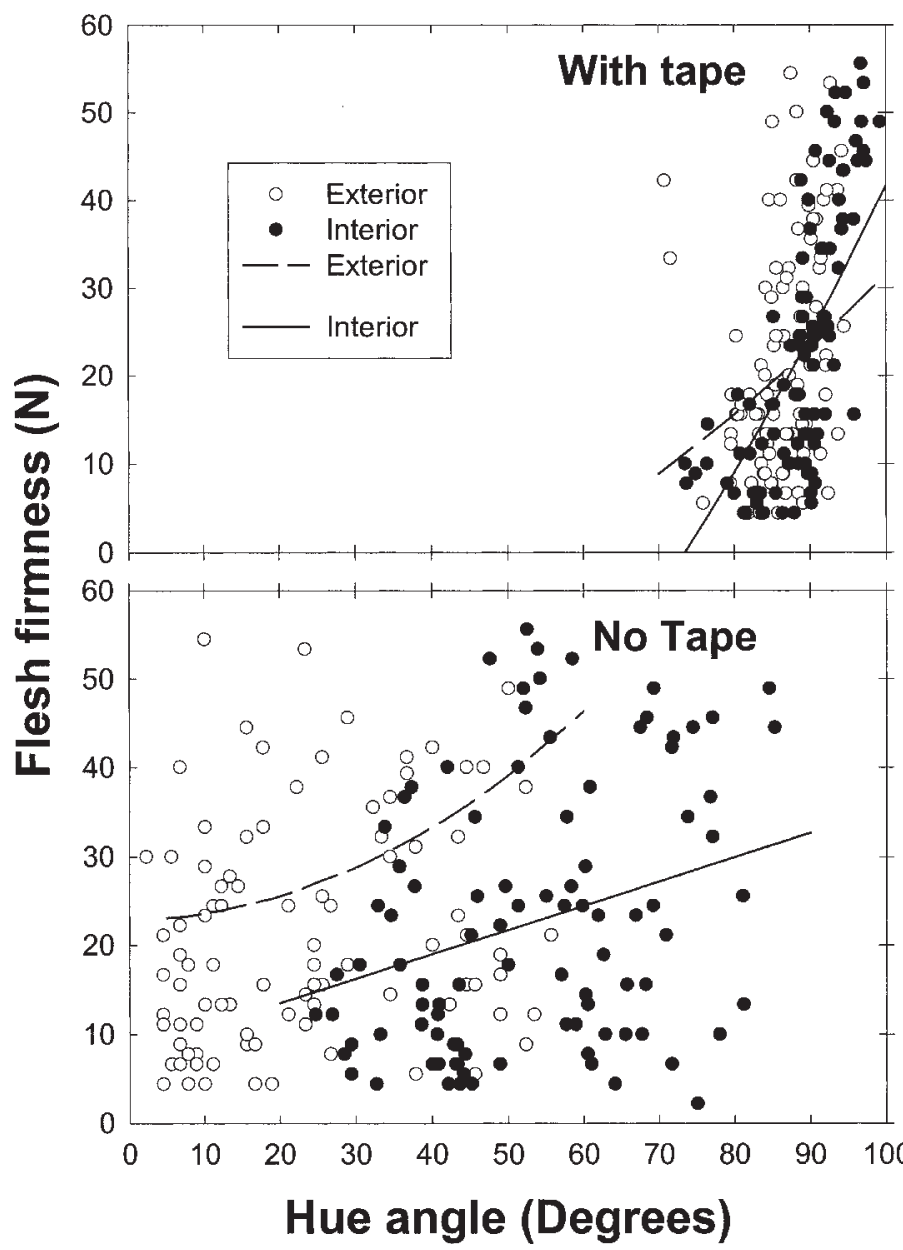

Fig. 3. The relationship between flesh firmness $(\mathrm{N})$ and hue angle measured next to and under a piece of tape on the nonblush side of 'Cresthaven' peaches in 2000 (Expt. 3). Regression models: For exterior fruit $(\bigcirc)$ measured under tape; flesh firmness $(\mathrm{N})=-40.36+0.732$ (hue angle), $r^{2}=0.18, \mathrm{n}=97, P=0.003$; for interior fruit $(\bigcirc)$ measured under tape, flesh firmness $(\mathrm{N})=-109.55+1.52$ (hue angle), $r^{2}=0.58, \mathrm{n}=93, P=0.001$; For exterior fruit measured next to tape; fruit firmness $(\mathrm{N})=112.8-3.2$ (hue angle) +0.03 (hue angle $\left.{ }^{2}\right), r^{2}=0.32, \mathrm{n}=97, P=$ 0.001 ; for interior fruit measured under tape, fruit firmness $(\mathrm{N})=3.84+-$ 0.37 (hue angle), $r^{2}=0.14, \mathrm{n}=93, P=0.005$. $\mathrm{L}^{*}=$ lightness; chroma $=\left[\left(\mathrm{a}^{* 2}+\right.\right.$ $\left.\left.\mathrm{b}^{* 2}\right)^{1 / 2}\right]$; hue angle $=$ arctangent $\mathrm{b} * / \mathrm{a}^{*}$, where $0^{\circ}=$ red-purple, $90^{\circ}=$ yellow, $180^{\circ}$ $=$ bluish-green, and $270^{\circ}=$ blue.
Natural shade in commercial orchards would probably not be severe enough to influence fruit firmness. However, these results and those previously reported (Marini et al., 1991) indicate that reduction in assimilate supply caused by defoliation or extremely cloudy weather, may negatively influence fruit firmness, especially for fruit developing in shaded regions of the canopy.

In the 'Norman' experiment, it was difficult to evaluate the relationship between ground color and fruit firmness because fruit developing in high light environments developed red color. Red color is not well related to maturity (Haller, 1952). Covering the entire fruit with foil effectively prevented red color development, but it also influenced other fruit characteristics. Covered fruit were heavier, softer, and had lower SSC than noncovered fruit (Table 3). Erez and Flore (1986) also reported that fruit covered with foil were softer than noncovered fruit, but foil did not affect ethylene evolution from the fruit. Loreti et al. (1993) reported that the increased water content, greater fruit weight, and reduced fruit flesh firmness of covered fruit suggested that depriving the fruit of light somehow interfered with the formation and composition of flesh cell walls, making them more elastic and enabling them to swell and contain more water. The relationship between hue angle of the nonblushed side of noncovered fruit and fruit firmness was again significantly influenced by canopy position for 'Cresthaven'. When harvested with orange to red-orange ground color (hue angles $<65^{\circ}$ ) exterior fruit were firmer than interior fruit. When harvested with orangeyellow to yellow ground color (hue angles $70^{\circ}$ to $90^{\circ}$ ) interior fruit were firmer than exterior fruit. When fruit were covered to prevent red color development, canopy position did not affect the relationship between ground color and fruit firmness.

Results with 'Cresthaven' indicate that the relationship between fruit firmness and hue angle was probably due to the presence of anthocyanin in the fruit skin, which was directly influenced by light rather than canopy position. To test this hypothesis, a piece of duct tape was placed on the nonblush side of 'Cresthaven' fruit developing at exterior and interior canopy positions. This treatment prevented development of anthocyanin under the tape without influencing other fruit quality characteristics. The relationship between fruit firmness and hue angle on the nonblush side of the fruit without tape was again influenced by canopy position. However, unlike previous experiments, exterior fruit were firmer than interior fruit regardless of hue angle (Fig. 3). There is no apparent explanation for these conflicting results. Some of the discrepancy may be explained by the fact that greener fruit with less red color were harvested from the tree interior, and the variation in flesh firmness explained by the variation in hue angle was fairly small. The influence of canopy position on the relationship between fruit firmness and ground color seems to vary with year, and possibly with cultivar. The tape effectively prevented red color development (Fig. 3), and results were similar to results with foil-covered fruit. The regression models were not significantly different for the two canopy positions.

In commercial operations, peaches must be harvested with adequate maturity to develop acceptable eating quality, but fruit must also be firm enough to withstand storage and shipping. Ground color is the primary criterion of maturity used for commercial peach harvest. Although several studies indicate that there is a relationship between ground color and maturity (Delwiche and Baumgardner, 1983, 1985; Upshall, 1946), our data indicate that the relationship between ground color and firmness is fairly poor $\left(r^{2}=0.45\right.$ to 0.70$)$, and the relationship may not always be linear. In all of our experiments, fruit harvested with a specific hue angle on the nonblush side had a wide range of firmness. Some peach researchers (Blake et al., 1931; Coe, 1933; Haller, 1952) questioned the usefulness of ground 
color as a direct index of maturity because it differs at the same stage of maturity in peaches from trees with different growth status and with seasonal conditions. Peaches from low-vigor trees were more yellow at the same firmness as those from high-vigor trees (Blake et al., 1931; Blake and Davidson, 1936; Coe, 1933). Ground color at maturity may also vary with crop load (Morris, 1932) and seasonal conditions (Willison, 1941).

The three primary groups of pigments in peach skin include chlorophylls, anthocyanins, and carotenoids. Light is required for synthesis and maintenance of chlorophyll (Goodwin, 1988) and anthocyanin (Proctor and Lougheed, 1976), but carotenoids may increase in the dark (Goodwin, 1988). Therefore, the red and green components of fruit color are influenced by light environment and may mask changes in yellow color. When covering the fruit surface prevented anthocyanin synthesis, the firmness range of fruit with orange-yellow to yellow ground color $\left(80^{\circ}\right.$ to $\left.90^{\circ}\right)$ was 5 to $50 \mathrm{~N}$. Therefore, there seems to be a poor relationship between ground color and peach fruit firmness and this relationship may be altered by factors influencing fruit surface color, such as season, cultivar, and light interception.

\section{Literature Cited}

Addoms, R.M., G.T. Nightingale, and M.A. Blake. 1930. Development and ripening of peaches as correlated with physical characteristics, chemical composition, and histological structure of the fruit flesh: II. Histology and microchemistry. N.J. Agr. Expt. Sta. Cir. 507.

Basiouny, F.M. and D.W. Buchanan. 1977. Fruit quality of Sungold nectarine as influenced by shade and sprinkling. Soil Crop Sci. Soc. Fla. Proc. 36:130-132.

Bible, B. and S. Singha. 1993. Canopy position influences CIELAB coordinates of peach color. HortScience 28:992-993.

Blake, M.A., O.W. Davidson, R.M. Addoms, and G.T. Nightingale. 1931. Development and ripening of peaches as correlated with physical characteristics, chemical composition, and histological structure of the fruit flesh: I. Physical measurements of growth and flesh texture in relation to the market and edible qualities of the fruit. N.J. Agr. Expt. Sta. Cir. 525.

Blake, M.A. and O.W. Davidson. 1936. Some studies of the degree of maturity of peaches at harvest in relation to flesh firmness, keeping quality, and edible texture. N.J. Agr. Expt. Sta. Cir. 606.

Coe, F.M. 1933. Peach harvesting studies. Utah Agr. Expt. Sta. Bul. 241.

Dann, I.R. and P.H. Jerie. 1988. Gradients in maturity and sugar levels of fruit within peach trees. J. Amer. Soc. Hort. Sci. 113:27-31.

Daane, K.M., R.S. Johnson, T.J. Michailider, C.H. Crisosto, J.W. Dlott, H.T. Ramirez, G.Y. Yokota, and D.P. Morgan. 1995. Excess nitrogen raises nectarine susceptibility to diseases and insects. Calif. Agr. 49:1318.

Delwiche, M. and R.A. Baumgardner. 1983. Ground color measurements of peach. J. Amer. Soc. Hort. Sci. 108:1012-1016.

Delwiche, M. and R.A. Baumgardner. 1985. Ground color as a peach maturity index. J. Amer. Soc. Hort. Sci. 110:53-57.

Erez, A. and J.A. Flore. 1986. The qualitative effect of solar radiation on 'Redhaven' peach fruit skin color. HortScience 21:1424-1426.

Fishman, M.L., B. Levaj, D. Gillespie, and R. Scorza. 1993. Changes in the physico-chemical properties of peach fruit pectin during on-tree ripening and storage. J. Amer. Soc. Hort. Sci. 118:343-349.

Francis, F.J. 1980. Color quality evaluation of horticultural crops. HortScience 15:58-59.

Genard, M. and C. Bruchou. 1992. Multivariate analysis of within-tree factors accounting for the variation of peach fruit quality. Scientia Hort. 52:37-51.

Goodwin, T.W. 1988. The biochemistry of the carotenoids. Chapman and Hall, New York.

Haller, M. 1952. Handling, transportation, storage, and marketing of peaches. USDA Circ. 21.

Layne, D.R., Z. Jiang, and J.W. Rushing. 2001. Tree fruit reflective film improves red skin coloration and advances maturity in peach. HortTechnology 11:234-242.

Littell, R.C., R.J. Freund, and P.C. Spector. 1991. SAS system for linear models. SAS Inst., Cary, N.C.

Littell, R.C., G.A. Milliken, W.W. Stroup, and R.D. Wolfinger. 1996. SAS system for mixed models. SAS Inst., Cary, N.C.

Long J.F. and B.K. Webb. 1973. Correlations of reflectance to maturity for whole peaches. Trans. Amer. Soc. Agr. 16:992-925.

Loreti, F., S. Morini, R. Muleo, C. Masetti, and C. Vitagliano. 1993. Effect of solar radiation deprival on selected parameters of peach fruit. Adv. Hort. Sci. 7:105-108.

Marini, R.P. 1985. Vegetative growth, yield, and fruit quality of peach as influenced by dormant pruning, summer pruning, and summer topping. J. Amer. Soc. Hort. Sci. 110:133-139.

Marini, R.P. and M.C. Marini. 1983. Seasonal changes in specific leaf weight, net photosynthesis, and chlorophyll content of peach leaves as affected by light penetration and canopy position. J. Amer. Soc. Hort. Sci. 108:600-605.

Marini, R.P., D. Sowers, and M.C. Marini. 1991. Peach fruit quality is affected by shade during final swell of fruit growth. J. Amer. Soc. Hort. Sci. 116:383-389.

Marini, R.P. and J.R. Trout. 1984. Sampling procedures for minimizing variation in peach fruit quality. J. Amer. Soc. Hort. Sci. 109:361-364.

McGuire, R. 1992. Reporting of objective color measurements. HortScience 27:1254-1255.

Morris, O.M. 1932. Peach maturity at harvest as related to quality. Wash. Agr. Expt. Sta. Cir. 266.

Pickett, W.F. 1935. Photosynthetic activity and internal structure of apple leaves are correlated. Proc. Amer. Soc. Hort. Sci. 32:81-85.

Pressy R. and J.K. Avants. 1973. Separation and characterization of endopolygalacturonase and exopolygalacturonase from peaches. Plant Physiol. 52:252-256.

Proctor, J.T.L. and E.C. Lougheed. 1976. The effect of covering apples during development. HortScience 11:108-109.

Rom, C.R., D.C.Ferree, and G.A. Cahoon. 1984. The influence of three tree training systems within hedgerows on light distribution, cropping, and efficiency of 'Redhaven' and 'Redskin' peaches. Ohio Agr. Res. Dev. Ctr. Cir. 283:49-53.

Salunkhe, D.K. and S.S. Kadam. 1995. Handbook of fruit science and technology. Marcel Dekker, New York.

Seymour, G.B., J.E. Taylor, and G.A. Tucker. 1993. Biochemistry of fruit ripening. Chapman \& Hall, London.

Sims, Jr., E.T. and D. Comin. 1963. Evaluation of objective maturity indices for 'Halehaven' peaches. Proc. Amer. Soc. Hort. Sci. 82:125130.

Thai, C.N. and R.L. Shewfelt. 1990. Peach quality changes at different constant storage temperatures: Empirical models. Trans. Agr. 33:227233.

Upshall, W.H. 1946. Fruit maturity and quality. Cultural methods for better quality peaches. Ont. Dept. Agr. Bul. 447.

Willison, R.S. 1941. Studies in maturity and cold storage of peaches. Sci. Agr. 21:624-645.

Wooge, J.D. and J.A. Barden. 1987. Seasonal changes in specific leaf weight and leaf anatomy of apple. HortScience 22:292-294. 